\title{
Erosion Risk Potential Assessment Using GIS and RS for Soil and Water Resource Conservation Plan: The Case of Yisir Watershed, Northwestern Ethiopia
}

\author{
Habtamu Tadele Belay ${ }^{1, ~ *}$, Demelash Ademe Malede ${ }^{1}$, Firaol Befekadu Geleta ${ }^{2}$ \\ ${ }^{1}$ Department of Natural Resources Management, Debre Markos University, Burie Campus, Burie, Ethiopia \\ ${ }^{2}$ Ethiopian Construction Design and Supervision Works Corporation, Surveying, Geospatial and Civil Informatics Center, Addis Ababa, \\ Ethiopia
}

\section{Email address:}

habtietoo@gmail.com (H. T. Belay), demelashade@gmail.com (D. A. Malede), freolyad@gmail.com (F. B. Geleta)

${ }^{*}$ Corresponding author

\section{To cite this article:}

Habtamu Tadele Belay, Demelash Ademe Malede, Firaol Befekadu Geleta. Erosion Risk Potential Assessment Using GIS and RS for Soil and Water Resource Conservation Plan: The Case of Yisir Watershed, Northwestern Ethiopia. Agriculture, Forestry and Fisheries.

Vol. 9, No. 1, 2020, pp. 1-13. doi: 10.11648/j.aff.20200901.11

Received: August 18, 2019; Accepted: February 21, 2020; Published: March 10, 2020

\begin{abstract}
Soil erosion is more sensitive in the highlands of Ethiopia. The purpose of this study is evaluating erosion risk potential using RUSLE model with GIS and remote sensing to identify erosion potential areas for soil and water resources conservation plan and to prepare soil loss risk map. Collected data were processed and analyzed using Arc GIS10.2 version. Total average annual soil loss from the 2,120.33ha was estimated at 7161.06 tons. The lower soil loss rate was $2.5 \mathrm{t} / \mathrm{ha} / \mathrm{yr}$ on plantation and natural forest, the maximum value was $100.62 \mathrm{tons} / \mathrm{ha} / \mathrm{yr}$ in steep slope cultivated land and average soil loss was $50.31 \mathrm{tons} / \mathrm{ha} / \mathrm{yr}$. About $6.35 \%$ of the area is under extremely very severe soil erosion rate. Level soil bund, graded soil, stone or stone faced soil bund, fanyajju, cutoff- drain in the above part of the catchment, waterway along the slope, trenches on grazing land, check dam SWC measures at Quala got, integrated physical with biological measures like tree Lucerne, Vetiver grass are the recommended SWC measures. This approach can be applied in other basin or watershed for assessment of erosion risk potential using GIS and RS, and this can be used as a preliminary watershed planning tool for decision makers in Ethiopia like Woreda Agriculture and Natural Resources management Office.
\end{abstract}

Keywords: Ethiopia, GIS, RUSLE, Soil and Water Resource, Yisir Watershed

\section{Introduction}

Soil erosion by water has been the most serious environmental problem in Ethiopia since the 1970s [1]. A study revealed that, 30 years ago the average annual soil loss rate was 1500 million tons per year, but currently it is 940 million tons per year [2]. Loss of these sediments also entails a huge loss of nutrients ( $\mathrm{N}$ and $\mathrm{P}$ ) [2]. The economic implication of soil erosion is more serious in the Northwestern highlands of Ethiopia because of its uneven topographical features and lack of capacity to cope with it to replace lost nutrients $[3,4]$ probably due to high population pressure which leads to intensified use of already stressed resources and cultivation of marginal and fragile lands. In Amhara region, the annual rate of soil loss estimated due to water erosion was about 119 million $\mathrm{t} / \mathrm{yr}$, which amounts to $70 \%$ of the total soil loss in the country as a whole [5]. Due to this reason $29 \%$ of the total area of the region experiences high erosion rates (51 $\mathrm{t} / \mathrm{ha} / \mathrm{yr}) ; 31 \%$ experiences moderate erosion rates (16 $\mathrm{t} / \mathrm{ha} / \mathrm{yr}) ; 10 \%$ experiences very high erosion rates $(>200$ $\mathrm{t} / \mathrm{ha} / \mathrm{yr}$ ); and the remaining $30 \%$ experiences low erosion rates $(<16 \mathrm{t} / \mathrm{ha} / \mathrm{yr})[6]$. This situation will become worse if increasingly marginal land is cultivated. In addition to continuous impacts of humans on cultivated land, grazing land is becoming scarce, and what remains is thereby exposed to extreme grazing pressure [5]. This has resulted in low and declining agricultural productivity and continuing food insecurity and rural poverty [7]. Poverty then drives populations to expand cultivated land to steep 
slope areas, which could, in turn, accelerates soil erosion [8].

Estimating soil loss rate using geospatial data have a great role in the decision making and to recommend soil and water conservation measures for hot spot area. Conventional methods can be used to estimate soil loss; however, it is expensive and time consuming. Currently, the RUSLE integrated with GIS and remote sensing is widely used to predict soil erosion rate and also it spatial extent because of its speedy and accuracy [9]. In the study area soil loss due to water erosion is not estimated even if there are gully and rill erosion problem. Therefore, this study aimed to estimate soil loss rate using RUSLE model combined with Geographic Information System (GIS) and remote sensing techniques. Specific objectives of this study were: to compute RUSLE factor raster layer; to estimate average annual soil loss rate using GIS and RS techniques; to identify severity areas and prioritize areas for specific soil and water conservation plans and to prepare soil loss risk map.

\section{Methods}

The study was conducted at Yisir watershed which is located in between Burie and Guagusa Shikudad District, Northwestern Ethiopia (Figure 1). Its area is 2120.33 ha. It is located between latitude of $10^{\circ} 43^{\prime} 0^{\prime \prime}$ to $10^{\circ} 47^{\prime} 0^{\prime \prime}$ North and longitude of $37^{\circ} 3^{\prime} 0^{\prime \prime}$ to $37^{\circ} 6^{\prime} 0^{\prime \prime}$ East, and at about $148 \mathrm{~km}$ Southwest of Bahir Dar city. The altitude ranges from 2087 to 2,637 meter above sea level.

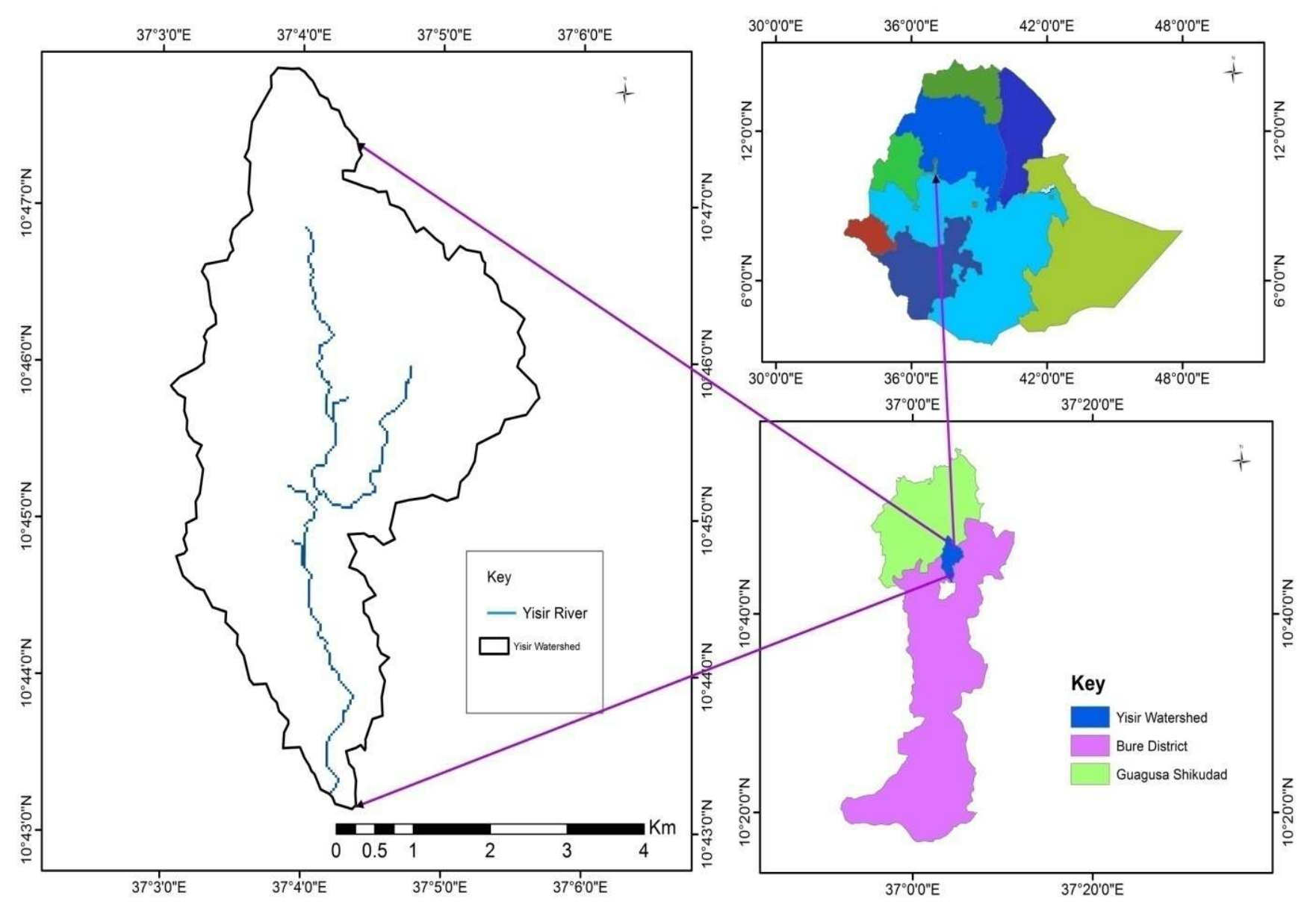

Figure 1. Location map of the study area.

\subsection{Methods of Data Collection}

The study was conducted using both primary and secondary data sources. Secondary data like rainfall data were collected from meteorological stations and the assigned RKCP factors from literature review for Ethiopian conditions. Primary data were collected using field survey or ground truth points and field observations of the watershed including management practices, land use/cover and soil color at top soil depth $(15 \mathrm{~cm})$.

\subsection{Data Sources}

\subsubsection{Digital Elevation Model}

ASTERDEM (a spatial resolution of $30 \mathrm{~m}$ ) was used to processes terrain data required for modeling of (Fill, flow direction, flow length, flow accumulation, slope gradient, stream order and watershed). The final result was used for topographic factor (LS) raster computation.

\subsubsection{Rainfall Data}

To compute R-factor mean annual rainfall data of 16 years 
(2001-2017) were collected from the nearby stations. Rainfal data were collected from four Amhara metrological stations (Burie distrct, Jabi Tehnan, Guagusa Shikudad, Shndi Wmberma) stations from neighbouring districts. The amount of rainfall was interpolated using Inverse Distance weighted (IDW) algorithm available in ArcGIS10.2.

\subsubsection{Soil Data}

The soil color types of the watershed was surveyed from the top soil depth $(15 \mathrm{~cm})$ using soil Munsell color chart and compared with estimated soil erodibility values for some soils [10]. From each land unit 32 soil samples (a total of 360 ) were collected using GPS with geographical coordinate system.

\subsubsection{Satellite Images}

LANDSAT satellite image which was used to classify and to classify land cover types of the study area was downloaded from (http://glovis.usgs.gov/) website acquired on January 2017.

\subsubsection{Field Data}

One hundred sixty ground control points were collected using Garmin GPS (72H) purposely for supervised land use/cover classification.

\subsection{Data Analysis Methods}

\subsubsection{Soil Loss Analysis}

The data was processed and analyzed using image analyst software (Arc GIS 10.2). The basic methodological approach followed in RUSLE model is illustrated in the following flow chart (Figure 2).

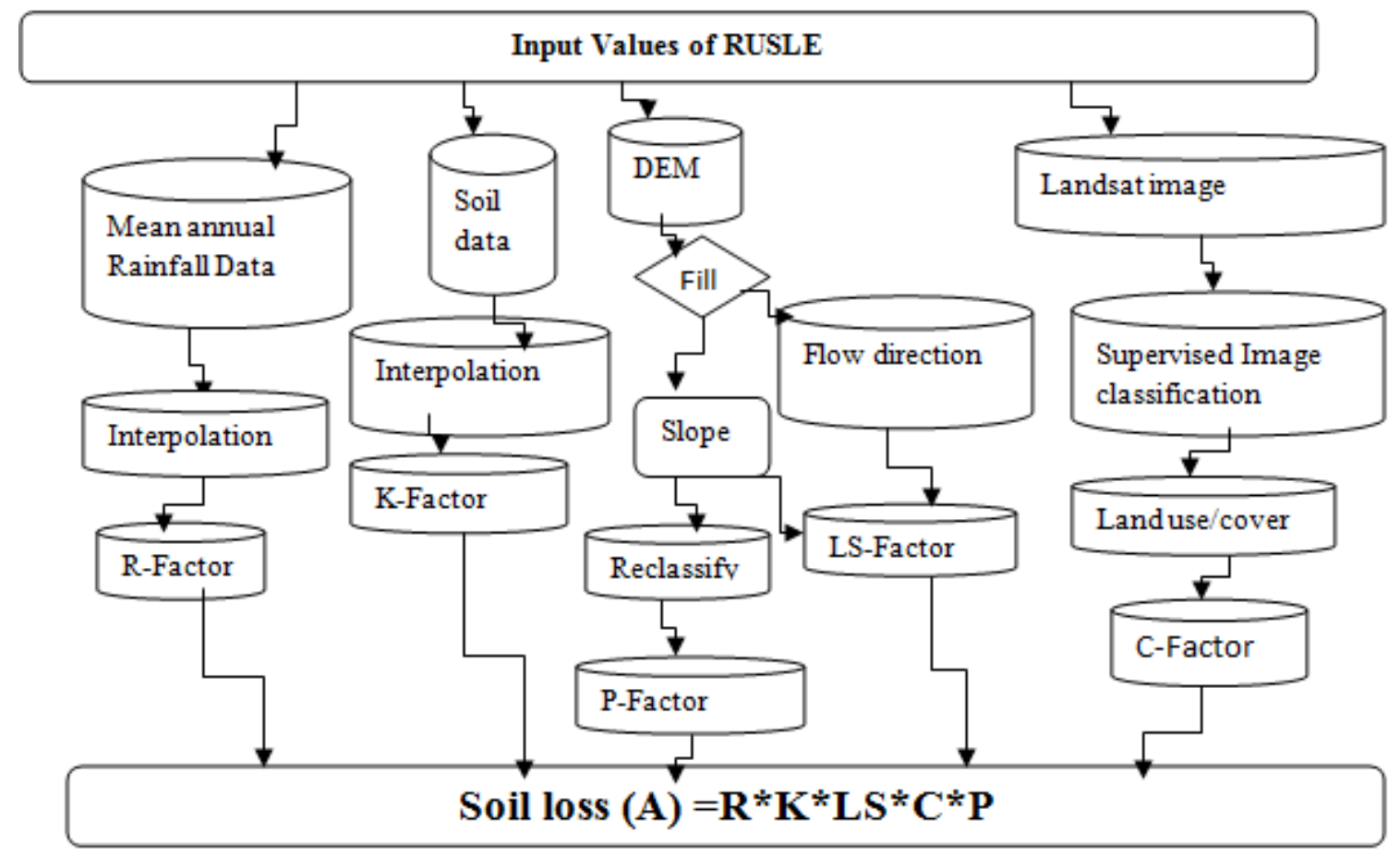

Figure 2. Procedure for analysis of soil loss rate using GIS and RS application methods.

\subsubsection{Derivation of RUSLE Parameters}

The annual soil loss rate and soil loss per hectare estimation was conducted by a cell-by-cell analysis of the soil loss surface by overlay and multiplying the respective RUSLE factor values (R, K, LS, C and P) interactively by using spatial analyst tool map algebra raster calculator in ArcGIS10.2 environment as shown Equation (1) adopted from the recommendations of [10]. For the purpose of identifying priority areas for conservation planning, soil loss potential of the study area first, it was categorized into different severity classes following FAO's basis of classification [11]. The data were interpreted qualitatively and using descriptive statistics.

$$
\mathrm{A}=\mathrm{R} * \mathrm{~K} * \mathrm{LS} * \mathrm{C} * \mathrm{P}
$$

Where: $\mathrm{A}$ is the annual soil loss (metric tons $\mathrm{ha}^{-1} \mathrm{year}^{-1}$ ); $\mathrm{R}$ is the rainfall erosivity factor $\left(\mathrm{MJ} \mathrm{mmh} \mathrm{ma}^{-1} \mathrm{year}^{-1}\right) ; \mathrm{K}$ is soil erodibility factor (metric tons $\mathrm{ha}^{-1} \mathrm{MJ}{ }^{-1} \mathrm{~mm}^{-1}$ ); LS is slope length factor (dimensionless); $\mathrm{C}$ is land cover and management factor (dimensionless) and $\mathrm{P}$ is conservation practice factor (dimensionless).

\section{i. Rainfall Erosivity Factor (R)}

The mean annual rainfall is first interpolated to generate continuous rainfall data for each grid cell using IDW interpolation technique in ArcGIS environment. Then, the Rvalue corresponds to the mean annual rainfall of the watershed is to be estimated using the R-correlation established to Ethiopia condition [10]. After calculating average 16 years of rainfall for each station $\mathrm{R}$ factor was computed using the above formula and converted in to raster surface. 


$$
\mathrm{R}=-8.12+0.562 * \mathrm{P}
$$

Where, $\mathrm{R}$ is rainfall erosivity and $\mathrm{P}$ is mean annual rainfall $(\mathrm{mm} / \mathrm{yr})$

\section{ii. Soil Erodibility Factor (K)}

A soil map of the study area was prepared through collecting GPS points of soil color at a depth of $15 \mathrm{~cm}$ with actual geographic coordinate system and then inverse distance weight (IDW) interpolation was done in ArcGIS environmemt. The value of $\mathrm{K}$ is given by based on soil colors in RUSLE for Ethiopian condition by adapting [10]. Reclassify the raster layer with assigned $\mathrm{K}$-factor value in ArcGIS10.2 spatial management tool. The soil erodibility (K) factor for the watershed was determined based on soil database adapted to Ethiopia by [10], [12]. Finally, the resulting shape-file was changed to raster with a cell size of $30 \mathrm{~m} \times 30 \mathrm{~m}$. The raster map was then reclassified based on their erodibility value. This is one input for RUSLE model.

\section{iii. Topographic Factor (LS) Factor}

Slope steepness has been considered as one of the most model parameters in RUSLE analysis due to the fact that the steeper the slope of a field, the more it is pushed down hill, the faster the water runs and the greater will be the amount of soil loss from erosion by water. The slope length and slope steepness factors are commonly combined in a single index as LS and referred to as the topographic factor and which expresses the ratio of soil loss from field slope length and the field slope gradient $(22.1 \mathrm{~m}$ under standard plot length and $9 \%$ under identical conditions) as defined by [13]. ASTER DEM was used to generate slope by using Spatial Analyst Tool Surface Slope in ArcGIS 10.2 environment. The fill, flow accumulation and slope steepness will be computed from the ASTERDEM using ArcGIS. Flow accumulation and slope maps are multiplied by using Spatial Analyst Tool Map Algebra Raster Calculator in Arc GIS 10.2 environment to calculate LS and to map the slope length (LS factor) as [13]. Flow Accumulation was derived from the DEM after conducting Fill and Flow Direction processes in ArcGIS 10.2. Finally, the LS factor map was derived using the above formula in ArcGIS spatial analysis raster calculator function.

$$
\text { LS }=(\text { Flow Accumulation } * \text { Cell size } / 22.13)^{0.4} *(\text { Sin slope } / 0.896)^{1.3}
$$

Where: Cell size is the field slope length, 22.13 is the length of the research field plot

\section{iv. Land-cover Management Factor (C)}

Land-cover management factor represents the ratio of soil loss under a given cover to that of the base soil [14]. A landuse and land-cover map of the study area was prepared from Landsat satellite image acquired on 2017 and supervised image classification technique was employed using ArcGIS software. Ground control points were collected using GPS reference for supervised classification by maximum likelihood algorithm for validation of the result was done. Through supervised image classification technique, land use/cover types were classified. The classified image is used as inputs for generating crop management $(\mathrm{C})$ factor. Based on the land use/cover classification map, a corresponding $\mathrm{C}$ value was assigned in a GIS environment for vector mapping of land use/cover [10].

\section{v. Conservation Practice Factor (P)}

In RUSLE, $P$ factor is the ratio of soil loss with a specific conservation practice to the corresponding loss with up and down slope cultivation, which has a value of one to zero [13]. The P-factor was assessed using major land use/cover and slope interaction adopted for Ethiopia [10]. The slope of the watershed was generated from DEM and classify based on FAO slope classes and reclassify the slope raster based on the respective $\mathrm{P}$ value with slope will be computed. The corresponding "P" values were assigned to each slope classes and the $\mathrm{P}$ factor map was done and conducted conversion from polygon to raster with output cell size of $30 \mathrm{~m}$ was the result of $\mathrm{P}$ factor raster map for Yisir watershed.

\section{Results and Discussions}

\subsection{Revised Universal Soil Loss Equation Model Factors}

\subsubsection{Rainfall Erosivity Factor (R)}

Rainfall erosivity depends on amount, intensity and distributions of rainfall. The soil loss is closely related to rainfall partly through the detaching power of raindrop striking the soil surface and partly through the contribution of rain to runoff [14]. Based on the analysis the minimum and the maximum (R) factor value is 814 to $1046 \mathrm{MJ} \mathrm{mmh}^{-1}$ $\mathrm{ha}^{-1} \mathrm{yr}^{-1}$, respectively (Figure 3 ). The northern part has high erosivity factor. This was due to the high mean annual rainfall of bordered District of Guagusa Shikudad. It should be noted that the higher erosivity value the more potential of the rainfall impacts to detach and transport the soil particles due to raindrop impacts.

\subsubsection{Soil Erodibility Factor}

As mentioned previously, [10] clearly indicated the relationship between soil colour and the K-value. Soils high in clays (Vertisols) tend to have low $\mathrm{K}$ values in terms of texture $(0.05$ to 0.15$)$ because it is more resistant to detachment [15]. The result shows that the $\mathrm{K}$-value ranges between 0.15 and 0.25 . Based on field survey and soil sample GPS points analyzed using soil color chart, the study area also have Black (Vertisols) and Brown (Cambisols) soil type [16]. The higher the K-factor value the more the soil vulnerabel to erosion and subsequently the higher soil loss under the ideal condition than the lower K-factor values of soil [15].

As can bee seen in Figure 4 and Table 1, most part of the study area was covered with Red (Nitisols) which is more 
vulnerable to erosion than other soil type. The result shows that $97 \%, 0.5 \%$ and $2 \%$ of the study area was covered with Nitisols, Vertisols and Cambisols, respectively. This means that most part of the study area is vulnerable to soil erosion.
But the remaining part of the study area, covered by Vertisols and Cambisols which is less vulnerable to soil erosion due to high cohesion force between its particles and low erodibility index value than Nitosols.

Table 1. Soil type, soil color and erodiblity factor in the study area.

\begin{tabular}{llllll}
\hline Sn. & Soil type & Soil color & K value & Area (ha) & Coverage (\%) \\
\hline 1 & Vertisols & Black & 0.15 & 10.62 & 0.50 \\
2 & Cambisols & Brown & 0.20 & 44.33 & 2.10 \\
3 & Nitisols & Red & 0.25 & 2065.38 & 97.40 \\
& Total & & & $2120.33 \mathrm{ha}$ & 100 \\
\hline
\end{tabular}

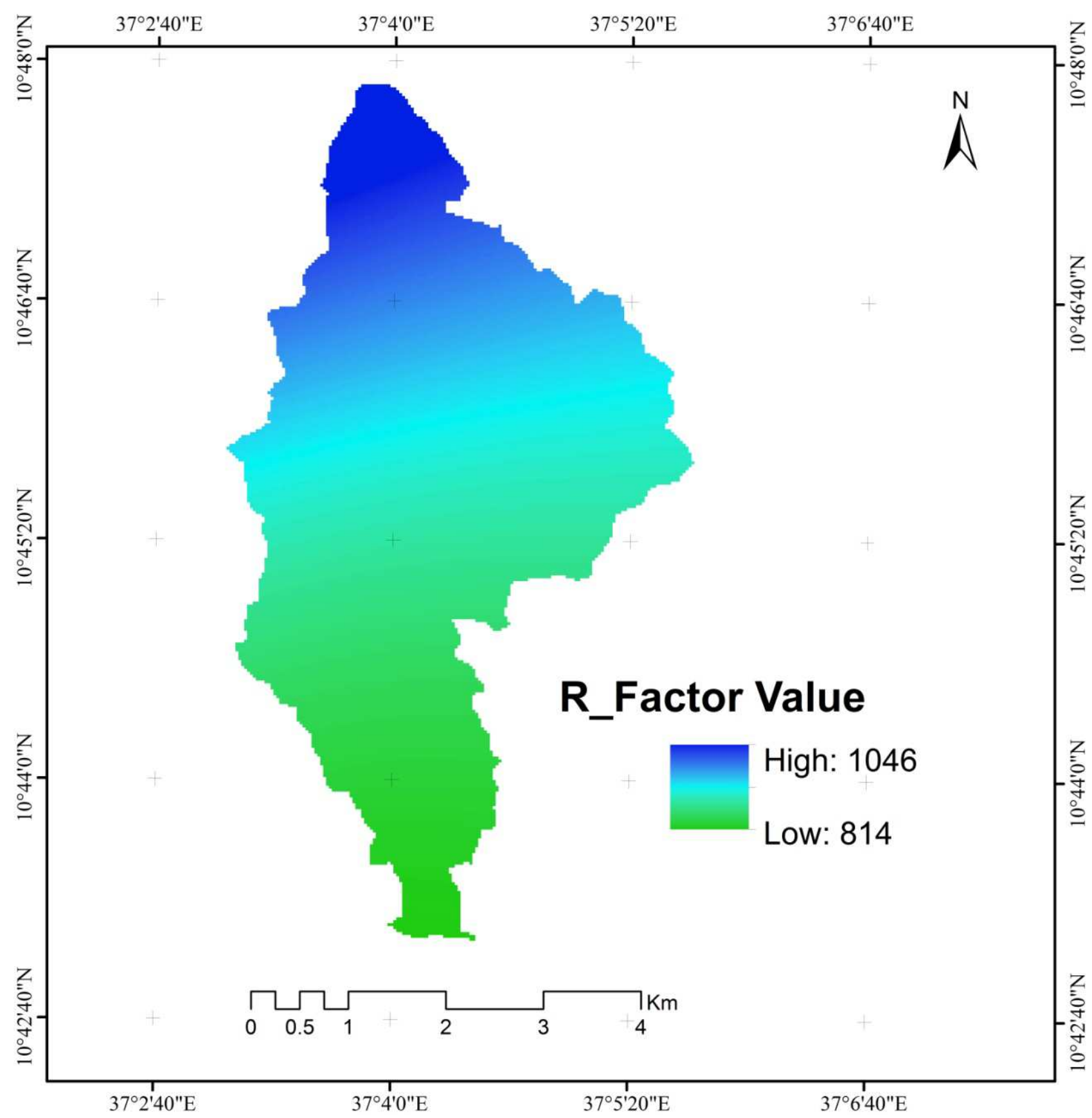

Figure 3. Rainfall erosivity factor (R). 


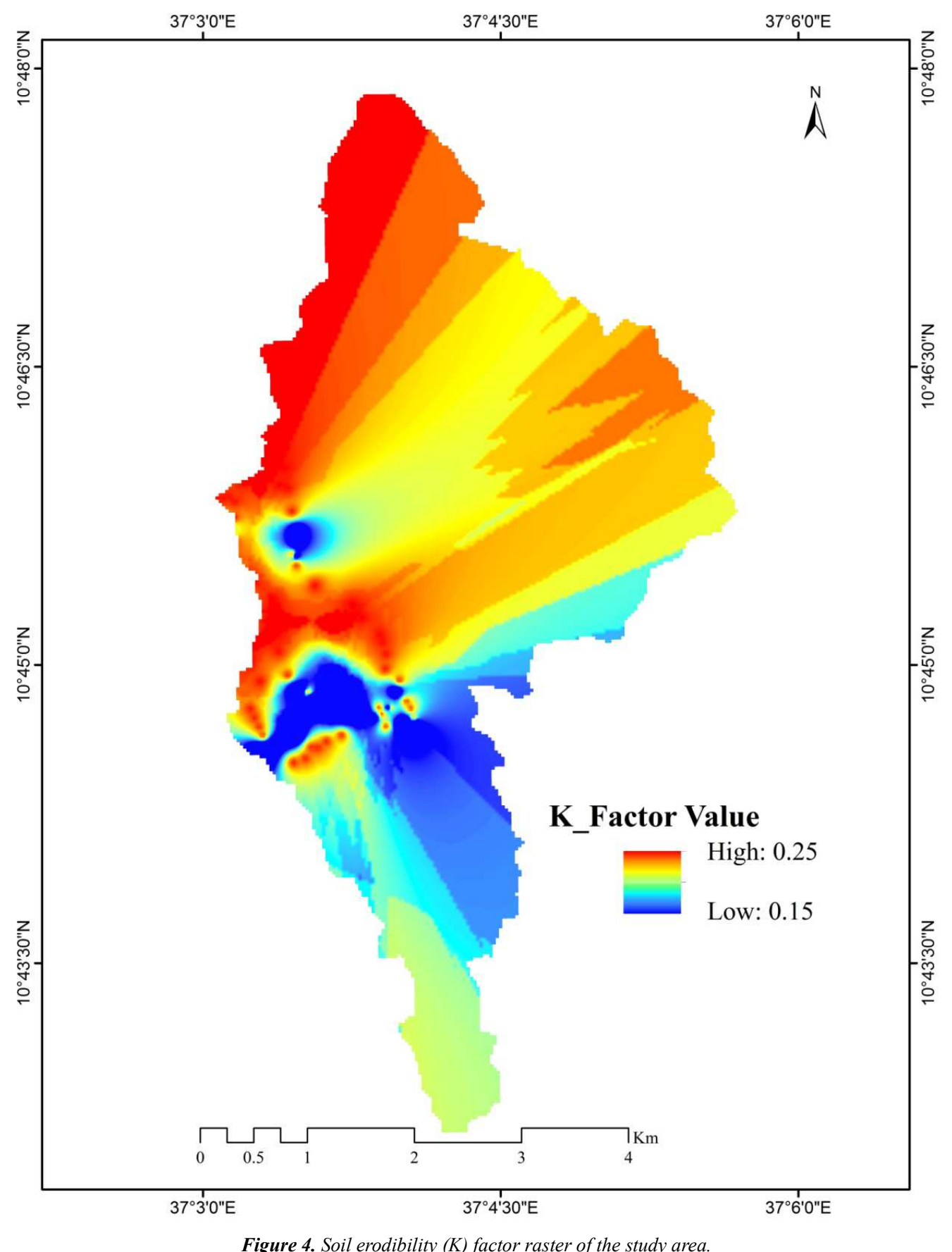

\subsubsection{Topographic Factor}

\section{Digital Elevation Model}

The modified (LS) factor map of the study area was generated from the slope and flow accumulation map derived from DEM. As slope length and gradient increases total soil eroded and soil loss per unit area may increase due to the progressive accumulation of runoff in the down slope direction. The result shows that the slope of the study area was ranged from $0 \%$ to $78 \%$ (Figure 5). This is in line with [17] as the slope length increases due to the greater accumulation of runoff by water erosion. The same author indicated that consolidation of small fields into larger ones often results in longer slope lengths with increased erosion potential due to increased velocity of water, which permits a greater degree of scouring [17]. The reason why the slope was classified in to six classes was done to know the topographic nature and landform class of the study area with its coverage.

Table 2. Slope class and area coverage of the study area.

\begin{tabular}{llll}
\hline Sn. & Slope class (\%) & Area (ha) & Percentage (\%) \\
\hline 1 & $0-2$ & 21.71 & 1.02 \\
2 & $2-8$ & 296.46 & 14.98 \\
3 & $8-15$ & 955.13 & 45.05 \\
4 & $15-30$ & 579.49 & 23.33 \\
5 & $30-50$ & 248.51 & 11.75 \\
6 & $50-78.13$ & 19.03 & 3.87 \\
Total & & 2120.33 ha & 100 \\
\hline
\end{tabular}




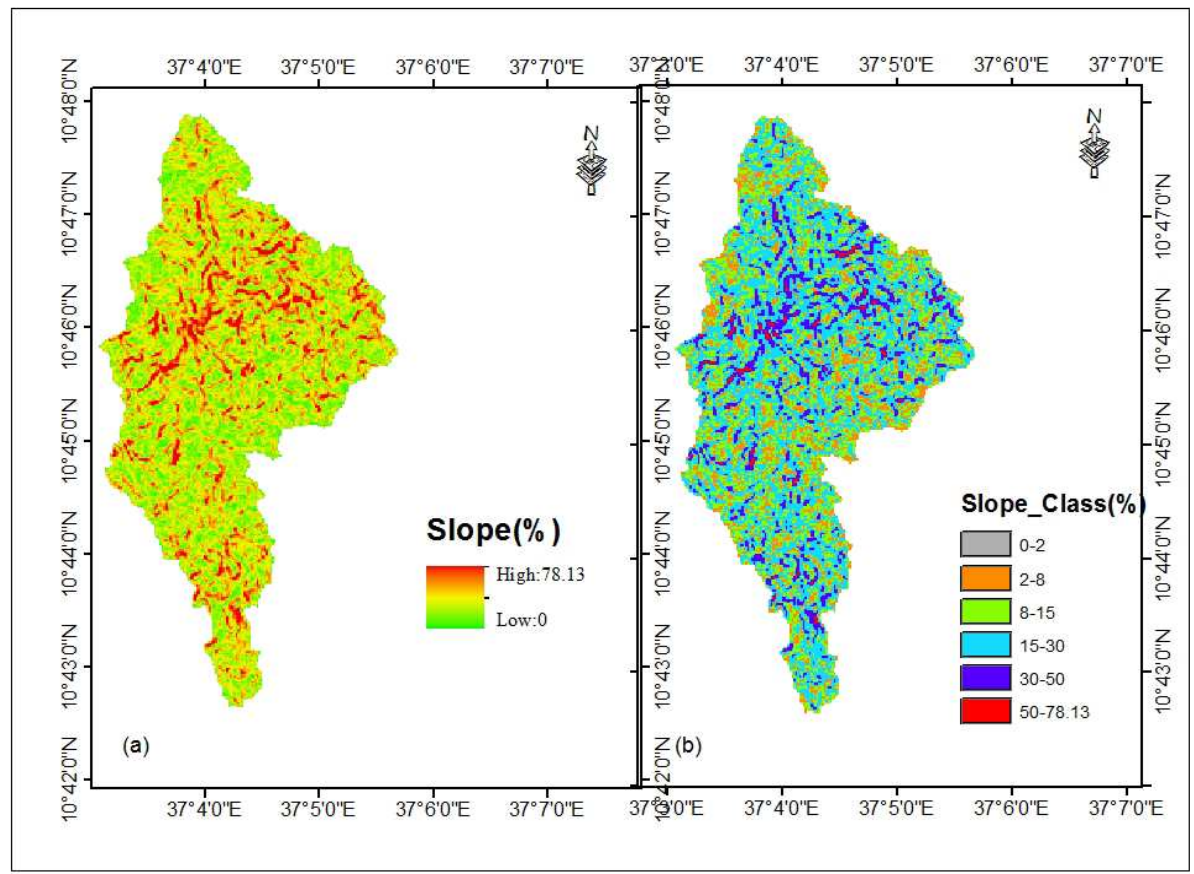

Figure 5. Slope range (a) slope class (b) of the study area.

In RUSLE slope length and slope gradient factors are considered as a single index value and it was used as an input layer for soil loss estimation. Therefore, in this study it was generated once within a short time by using equation 5 as shown in Figure 6. The LS factor ranged from 0 to 5.12 .

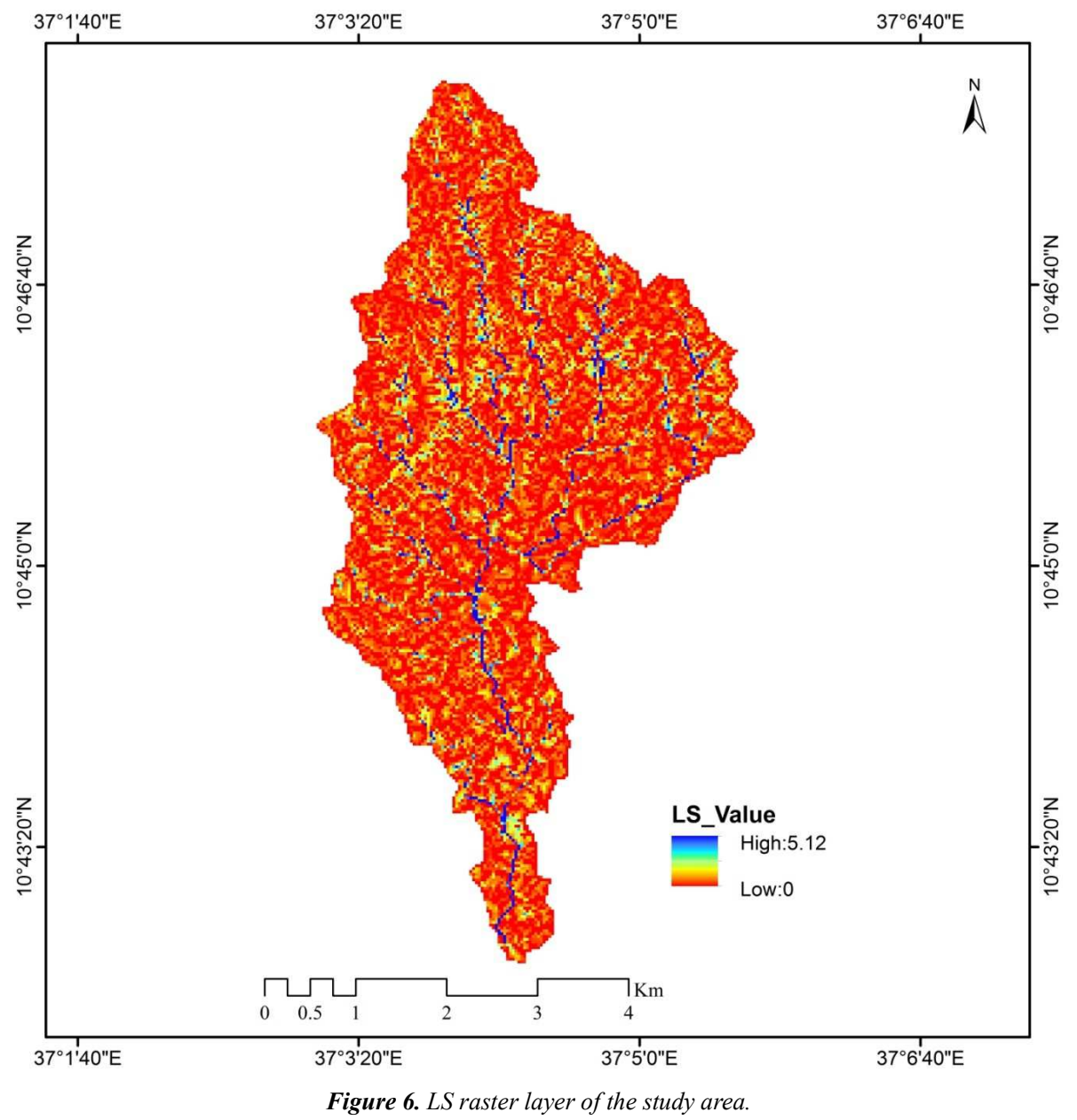




\subsubsection{Land Use/Cover Factor}

A total of 160 ground control points grazing (30 points), settlement (35 points), cultivated (35 points), plantation forest (30) and on forest land (30 points) were collected using handholding GPS. This data were used for supervised image classification.

Table 3. Land use/cover type and area coverage.

\begin{tabular}{llll}
\hline Sn. & Land use/cover & Area (ha) & Percent (\%) \\
\hline 1 & Cultivated & 1208.83 & 57.01 \\
2 & Settelment & 125.42 & 5.91 \\
3 & Grazing & 276.99 & 13.06 \\
4 & Plantation & 162.71 & 7.67 \\
5 & Natural forest & 346.38 & 16.38 \\
Total & & 2120.33 & 100 \\
\hline
\end{tabular}

Land cover plays a significant role to reduce rain drop impacts on soil particles. The dense vegetation covers less erosion process and subsequently low soil loss rate. Because of reducing runoff velocity, long horizontal movement and reduce potential energy [14]. As shown in Figure 7 five major land use/cover types were identified and the accuracy of the classified image is $89.78 \%$.

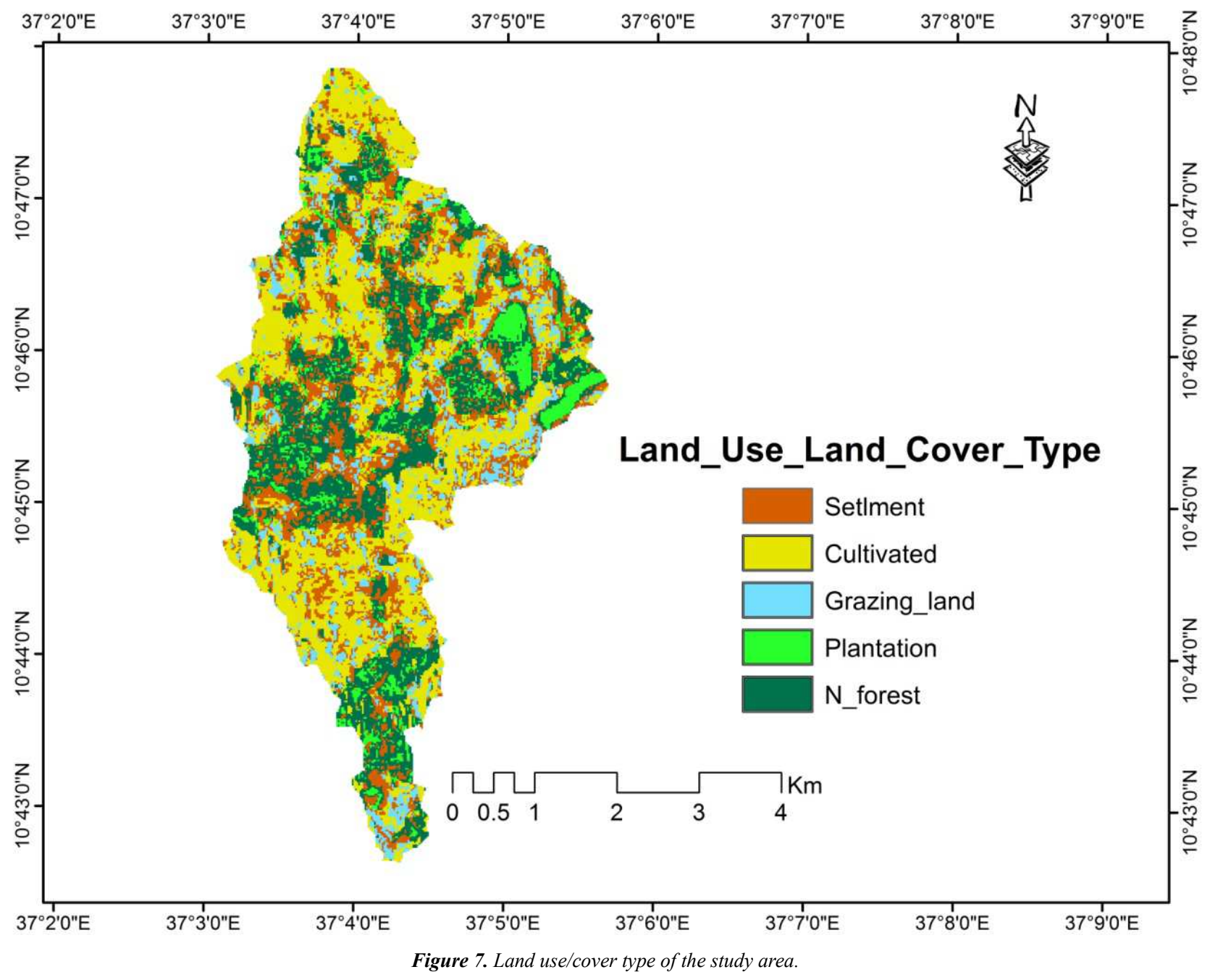

Based on the analysis (C) factor value of the study area is between 0.01 to 0.17 . The higher $\mathrm{C}$ value indicates that the specified land use/cover is highly vulnerable to soil erosion and the lower value in forest land indicated that less vulnerable land cover type in the study area. The $\mathrm{C}$ factor values with respective land use/cover type were $(0.01,0.14$, $0.17,0.02$ and 0.001$)$ in grazing, settlement, cultivated (cereals or pulse), plantation and forest (Figure 8). Cultivated land is exposed to erosion than other land use/cover that is why it has high $\mathrm{C}$ factor value. The $\mathrm{C}$-factor raster map value was high in the north direction because this area used for crop cultivation with poor land covers conditions. The lowest value was in most grazing land and forest land in the most central part, northeast and southwest of the study area. 


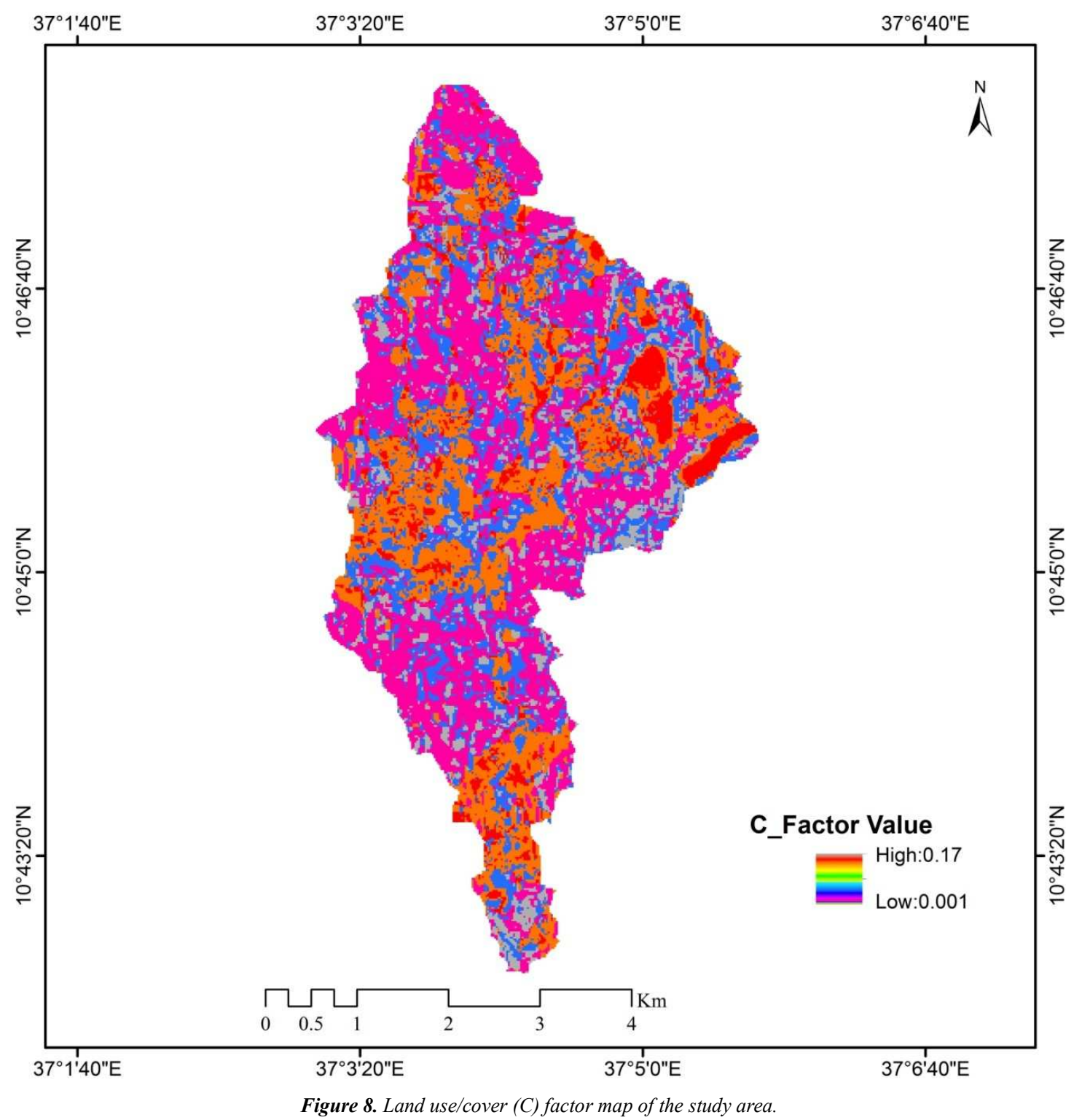

Table 4. Slope class derived from DEM and management factor values of the study area.

\begin{tabular}{lllll}
\hline Sn. & Slope class & Area (ha) & Percentage (\%) & (P) factor \\
\hline 1 & $0-5$ & 383.99 & 18.11 & 0.11 \\
2 & $5-10$ & 165.47 & 7.80 & 0.12 \\
3 & $10-20$ & 456.33 & 21.52 & 0.14 \\
4 & $20-30$ & 929.59 & 43.84 & 0.22 \\
5 & $30-50$ & 179.22 & 8.45 & 0.31 \\
6 & $51-78$ & 5.73 & 0.28 & 0.43 \\
Total & & 2120.33 & 100 & \\
\hline
\end{tabular}

\subsubsection{Management Practices Factor}

The study area was classified into six classes: slope gradient class one from 0 to $5 \%$, and class six from 51 to $78.13 \%$. As shown in Table 4 most part of the study area was in slope class of 10 to $20 \%$ and 20 to $30 \%$ and the area coverage was $21.5 \%$ and $43.8 \%$, respectively. The reason for classifying slope class in to six was to assign the respective $\mathrm{P}$ factor value in each class for $\mathrm{P}$ factor raster layer and to analyze the Percentage of each slope class. This is because the slope class percentage could be an indicator in which area the conservation measures should be implemented because of the slope nature of the targeted site.

For each slope class, respective P-value was assigned, which ranges between 0.11 to 0.43 . Then, the vector format was converted into raster format using ArcGIS. The higher the P- value the higher ratio of soil loss from conservation practiced land with up and down slope cultivated land and the lower supporting factor (P) the lower soil loss ratio. Practicing conservation measure can change the slope of land and also reduce soil erosion through improving soil physical and chemical properties. 


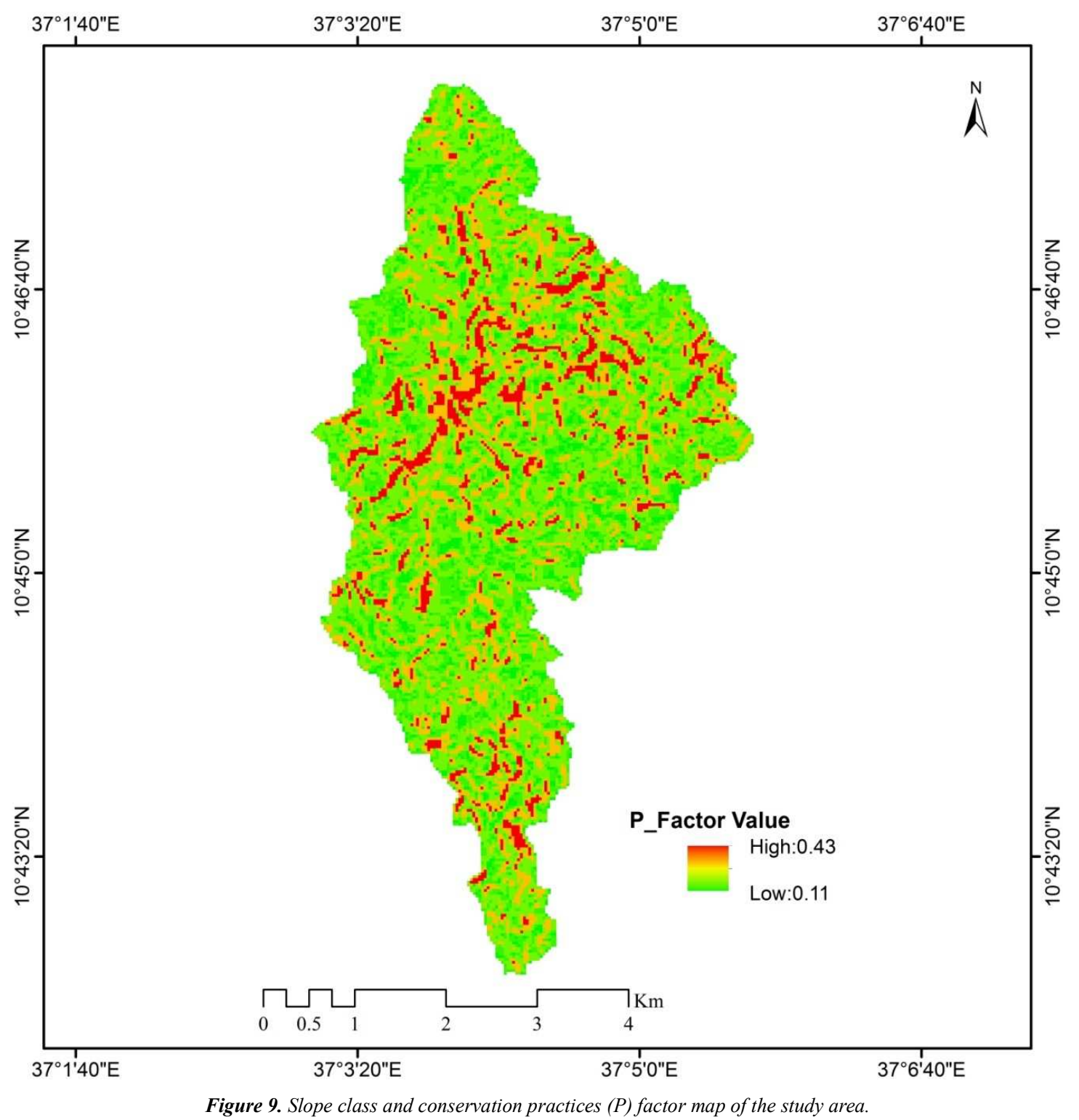

\subsection{Soil Loss Potential}

The RUSLE model (Equation I), created in the Arc-GIS, was used to generate a soil erosion risk map (Figure 10), and shows the spatial distribution of soil loss. Annual soil loss was estimated by overlaying soil loss factor raster layer after creating the RUSLE input data layers, i.e. R, K, LS, C and P factor map respectively using ArcGIS. Other researchers were also used the RUSLE for soil los estimation, for example $[18,19,20,21,22]$ in Ethiopia because of its simplicity and limited data requirement. The soil loss rate map shows various soil erosion rates with an estimated soil loss ranging from $2.5 \mathrm{t} / \mathrm{ha} / \mathrm{yr}$ in the plain areas and those covered with plantation forests, such as the Eucalyptus plantations, to a little over $100.62 \mathrm{t} / \mathrm{ha} / \mathrm{yr}$ in the areas of agricultural lands, waterways and drainages. The total annual soil loss in the study area (from an estimated area of 2,120.33 ha) was about 7161.06 tons. The average annual soil loss for the entire district was estimated at $50.31 \mathrm{t} / \mathrm{ha} / \mathrm{yr}$. About $96.6 \%$ of the study area was categorized very slightly to slightly class which was under soil loss tolerance (SLT) values ranging from 5 to $11 \mathrm{t} / \mathrm{ha} / \mathrm{yr}$ [23]. The remaining 3.4\% of the study area was classified under moderate to very severe class, which is higher than the maximum tolerable soil loss (18 t/ha/yr) in Ethiopia as reported by Hurni (1985). The class of soil loss ranged from very slight, slight, moderate, severe and very severe [24]. The maximum annual soil loss of the study area was $100.62 \mathrm{t} / \mathrm{ha} / \mathrm{yr}$. Soil loss risk in the study area was categorized under very slight class $(0-5$ $\mathrm{t} / \mathrm{ha} / \mathrm{yr})$, slight soil loss (5-11 t/ha/yr), moderate soil loss class (11-20 t/ha/yr), severe class of soil loss (20-30 t/ha/yr) and very severe class (30-100.62 t/ha/yr). It may be worth noting that nature takes 200 to 400 years to build up $1 \mathrm{~cm}$ of top soil but thousands tons of soil are lost in a season from a watershed [25]. In the study area the annual top soil eroded was ranged from 0 to $0.4 \mathrm{~cm}$ depth of soil (Table 5). As the researcher's knowledge soil loss due to soil erosion by water remove top soil and substantially it affects soil physicochemical properties negatively and reduces soil fertility status. 
Table 5. Soil loss summary of the study area.

\begin{tabular}{llllllll}
\hline tons/ha/yr & $\mathbf{m m} / \mathbf{y r}$ & Area (ha) & $\begin{array}{l}\text { Area Coverage } \\
\mathbf{( \% )}\end{array}$ & Severity classes & $\begin{array}{l}\text { Priority } \\
\text { class }\end{array}$ & $\begin{array}{l}\text { Average Annual } \\
\text { soil loss (tons) }\end{array}$ & Soil loss (\%) \\
\hline $0-5$ & $0-0.5$ & 1963.34 & 92.59 & Very slight & 5 & 4908.35 & 68.54 \\
$5-11$ & $0.5-1$ & 92.26 & 4.35 & Slight & 4 & 738.08 & 10.31 \\
$11-20$ & $1-2.5$ & 40.44 & 1.91 & Moderate & 3 & 626.82 & 8.75 \\
$20-30$ & $1-2.5$ & 17.33 & 0.82 & Severe & 2 & 433.25 & 6.05 \\
$30-100.62$ & $2.5-4$ & 6.96 & 0.33 & Very severe & 1 & 454.5576 & 6.35 \\
Total & & $2,120.33$ & 100 & & & 7161.0576 & 100 \\
\hline
\end{tabular}

Based on the analysis the average soil loss in the study area was $50.31 \mathrm{t} / \mathrm{ha} / \mathrm{yr}$. This is more than the maximum tolerable soil loss $(18 \mathrm{t} / \mathrm{ha} / \mathrm{yr})$ in Ethiopia [10]. Other studies conducted in the Ethiopian highlands also shows that the average soil loss is higher than the maximum tolerable soil loss rate. For example, the average annual soil loss at Guang watershed in north Gonder Zone was 24.95t/ha/yr [26]; in Koga watershed, north western Ethiopia it was $47.4 \mathrm{t} / \mathrm{ha} / \mathrm{yr}$ [22]; in Jabi Tehinan, north western Ethiopia at District level mean annual soil loss was $30.6 \mathrm{t} / \mathrm{ha} / \mathrm{yr}$ [4]; in north central highlands of Ethiopia was $30.88 \mathrm{t} / \mathrm{ha} / \mathrm{yr}$ [27], annual soil loss in Tigray, northwestern Ethiopia was $39.8 \mathrm{t} / \mathrm{ha} / \mathrm{yr}$ [28], the annual soil loss at Lalen watershed in Dangla and Fagita Lokoma Districts, Northwestern Ethiopia was $108 \mathrm{t} / \mathrm{ha} / \mathrm{yr}$ [29]. Therefore, the result of this study is higher as compared with the results from previous studies conducted in Northern Ethiopia except Dangla and Fagita Lokoma district which is highland area. As the knowledge of the researchers' soil erosion and its result i.e. soil loss is more in the lowland than highland area.

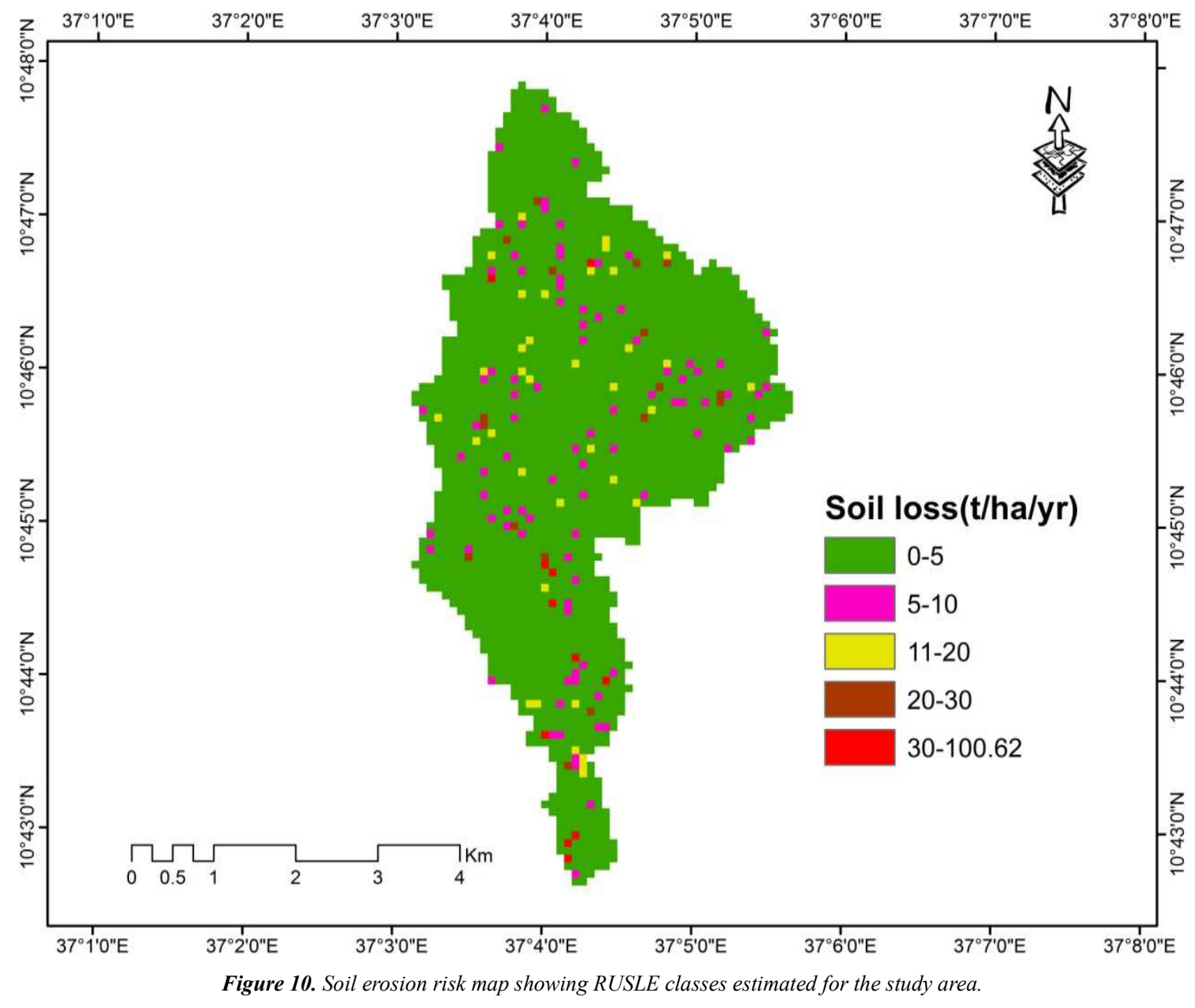

\section{Conclusion}

Comparison to other studies elsewhere in Ethiopia, the soil erosion risk map and the erosion severity classes generated using RUSLE model integrated with the Arc-
GIS10.2 revealed that, Yisir watershed landscape is under considerable soil erosion potential putting severe challenges to the agricultural productivity. The total average annual soil loss from the study area (an area of 2,120.33 ha) was estimated at 7161.06 tons. The lower soil loss rate was 2.5 $\mathrm{t} / \mathrm{ha} / \mathrm{yr}$ under plantation and natural forest, the maximum 
value was 100.62 tons/ha/yr in steep slope cultivated land and the average soil loss in the watershed was 50.31 tons/ha/yr. The entire study area was classified under five different erosion severity classes. About $96.94 \%$ of the study area is under SLT (11 t/ha/yr) level in having; while the remaining $3.06 \%$ is classified under moderate to very severe classes, contributing about $21.15 \%$ of the total soil loss in the area. About $6.35 \%$ is under extremely very severe soil erosion rate which needs imperative conservation measures. In Yisir watershed, the average annual soil loss was higher than the maximum tolerance value. The northern parts of the study area which is intensively cultivated and covered by Nitisols, grazing land with developed gully. In the study area there is visual rill and gully erosion problem.

\section{Acknowledgements}

We would like to thank Debre Markos University for funding the project and the study area development agents.

\section{References}

[1] Hurni H., Solomon Abate., Amare Bantider., Berhanu Debele., Ludi Evas., Portner Bbrgitte., BirruYitaferu. and Gete Zeleke, 2010. Land degradation and sustainable land management in the highlands of Ethiopia. In Hurni H, Wiseman U (Ed) with an international group of co-editors. Global change and sustainable development: A synthesis of regional experiences from research partnerships, Georaphica Bernensia, 5, pp. $187-$ 201.

[2] Hurni K., Gete Zeleke., Minale Kassie., Berhan Tegegne., Tibebu Kassawmar., Ermias Teferi., Aderajew Moges., Deme Tadesse., Mohamed Ahmed., Yohannes Degu., Zeleke Kebebew., Elias Hodel., Ahmed Amdihun., Asnake Mekuriaw., Berhanu Debele., Deichert G. and Hurni H, 2015. Economics of Land Degradation (ELD) Ethiopia Case Study. Soil Degradation and Sustainable Land Management in the Rainfed Agricultural Areas of Ethiopia: An Assessment of the Economic Implications. Report for the Economics of Land Degradation Initiative, pp. 94.

[3] Hurni H, 1993. Land degradation, famine, and land resource scenarios in Ethiopia. In: Pimentel D. World soil erosion and conservation. Cambridge University. Press, pp. 89-97.

[4] Tadesse Amsalu and Abebe Mengaw, 2014. GIS Based Soil Loss Estimation Using RUSLE Model: The Case of Jabi Tehinan Woreda, ANRS, Ethiopia, Natural Resources, 5, pp. 616-626.

[5] IFSP (Integrated Food Security Programme), 2004. Status report on the use of Vetiver Grass for soil and water conservation by GTZ IFSP South Gonder, Ethiopia. Integrated Food Security Programme. Bureau of Agriculture, Amhara Region, Bahir Dar, Ethiopia.

[6] Dessalew Meseret, 2016. Land Degradation in Amhara Region of Ethiopia: Review on Extent, Impacts and Rehabilitation Practices. PhD Scholar, Department of Bioscience, Mangalore University, India. Journal of Environment and Earth Science. Vol. 6, No. 1.
[7] Assemu Tesfa and Shigdaf Mekuriaw, 2014. The Effect of Land Degradation on Farm Size Dynamics and CropLivestock Farming System in Ethiopia: A Review. Journal of Soil Science, Vo. 4, pp. 1-5.

[8] Asnake Mekuriaw. and Hurni. H, 2015. Analyzing factors determining the adoption of environmental management measures on the highlands of Ethiopia. Civil and Environmental Research. Vol. 7, No. 12. ISSN 2224-5790.

[9] Bayramin I., Dengiz O., Baskan O. and Parlak M, 2002. Soil erosion risk assessment with ICONA model: Beypazari Area, Turk. Journal of Agriculture and Forestry, 27, pp. 221-229.

[10] Hurni H, 1985. Erosion Productivity Conservation Systems in Ethiopia. Proceedings $4^{\text {th }}$ International Conference on Soil Conservation, Maracay, Venezuela, pp. 654-674.

[11] FAO and UNEP, 1984. Provisional Methodology for Assessment and Mapping of Desertification. FAO, Rome, Italy.

[12] Hellden U, 1987. An Assessment of Woody Biomass, Community Forests, Land Use and Soil Erosion in Ethiopia, Lund University Press, Lund.

[13] Wischmeier W. H and Smith D. P, 1978. Predicting Rainfall Erosion Losses a Guide for Selection for Conservation Planning. Agricultural Handbook. S. Department of Agriculture, 537, pp. 69.

[14] Morgan R. P. C, 1994. Soil Erosion and Conservation. Silsoe College, Cranfield University, Cranfield.

[15] Yongsik Kim, 2014. Soil Erosion Assessment using GIS and Revised Universal Soil Loss Equation (RUSLE). CE 394K GIS in Water Resources, David R. Maidment, 05 Dec. 2014.

[16] Munsell Soil Color charts, 1992. U.S. Dept. Agriculture handbook 18 Soil survey manual. Revised edition. New York, pp. 12551-0230.

[17] Jim Ritter, 20015. Soil Erosion Causes and Effects, Order No. 87-040. P. Eng. Engineer, Soil Management. OMAFRA (Ontario Minstry os Agriculture Food and Rural Affairs), Factshees. France.

[18] Mellerowicz K. T., Ress H. W., Chow T. L. and Ghanem I, 1994. Soil conservation planning at the watershed level using the Universal Soil Loss Equation with GIS and microcomputer technologies: a case study. Journal of Soil and Water Conservation, 49, pp. 194-200.

[19] Kalenrieder V, 2007. Adaptation and Validation of the Universal Soil Loss Equation (USLE) for the Ethiopian Eritrean Highlands, MSc. Thesis University of Bern, Center for development and environment Switzerland.

[20] Bewket Woldamlak and Ermias Teferi, 2009. Assessment of soil erosion hazard and prioritization for treatment at the watershed level: case study in the Chemoga watershed, Blue Nile basin, Ethiopia. Land degradation and development. Published online in Wiley Inter Science (www.interscience.wiley.com) DOI: 10.1002/ldr.944.

[21] Gizachew Ayalew, 2015a. Geographic Information System Based Soil Loss and Sediment Estimation in Zingin Watershed for Conservation Planning, Highlands of Ethiopia. Amhara Design and Supervision Works Enterprise (ADSWE), Bahir Dar, World Applied Sciences Journal 33 (1), pp. 69-79. 
[22] Habtamu Sewnet and Amare Sewnet, 2016. Soil loss estimation using GIS and remote sensing techniques: A Case of Koga Watershed, Northwestern Ethiopia, international Soil and Water Conservation Research, http://dx.doi.org/10.1016/j.iswcr.01.002.

[23] Renard K. G., Foster G. R., Wessies G. A., McCool D. K. and Yoder D. C, 1996. Predicting Soil Erosion by Water: A Guide to Conservation planning with the Revised Universal Soil Loss Equation (RUSLE). USDA, Washington, DC.

[24] Singh R. and Phadke V. S, 2006. Assessing soil loss by water erosion in Jamni River Basin, Bundelkhand region, India, adopting universal soil loss equation using GIS. Current Science, 2006; 90 (10), pp. 25-27.

[25] Pimentel D. C, 1995. Environmental and economic cost of soil erosion and conservation benefits. 267 (5201), pp. 1117-1123.

[26] Gizachew Ayalew and Yihenew G. Selassie, 2015. Soil Loss Estimation for Soil Conservation Planning using Geographic
Information System in Guang Watershed, Blue Nile Basin, Ethiopia. Journal of Environment and Earth Science. Vol. 5, No. 1. ISSN 2224-3216.

[27] Abate Shiferaw, 2011. Estimating Soil Loss Rates for Soil Conservation Planning in Borena Woreda of South Wollo Highlands. Addis Ababa University, Ethiopia. Journal of Sustainable Development in Africa. Vol. 13, No. 3 (ISSN: 1520-5509).

[28] Estifanos Abera, 2014. Assessment of Micro Watershed Vulnerability for Soil Erosion using GIS and Remote Sensing; MSc. Thesis in GIS and remote sensing, Mekele University, Ethiopia.

[29] Gizachew Ayalew, 2015b. A Geographic Information System based Soil Loss Estimation in Lalen Watershed for Soil Conservation Planning, Highlands of Ethiopia. Journal of Dynamics in Agricultural Research Vol. 2 (3), pp. 31-39, Article ID: JDAR15/019. 